\title{
Identifying Symptoms of Bankruptcy Risk Based on Bankruptcy Prediction Models-A Case Study of Poland
}

\author{
Jerzy Kitowski (D), Anna Kowal-Pawul *(D) and Wojciech Lichota (D)
}

Citation: Kitowski, J.; Kowal-Pawul, A.; Lichota, W. Identifying Symptoms of Bankruptcy Risk Based on Bankruptcy Prediction Models-A Case Study of Poland. Sustainability 2022, 14, 1416. https://doi.org/ $10.3390 /$ su14031416

Academic Editors: Tomasz Kijek,

Giuliana Birindelli,

Aleksandra Kowalska

Arkadiusz Kijek and

Anna Matras-Bolibok

Received: 18 December 2021

Accepted: 23 January 2022

Published: 26 January 2022

Publisher's Note: MDPI stays neutral with regard to jurisdictional claims in published maps and institutional affiliations.

Copyright: (C) 2022 by the authors. Licensee MDPI, Basel, Switzerland. This article is an open access article distributed under the terms and conditions of the Creative Commons Attribution (CC BY) license (https:// creativecommons.org/licenses/by/ $4.0 /)$.
Institute of Economics and Finance, University of Rzeszów, 35-310 Rzeszow, Poland; kitowski@ur.edu.pl (J.K.); wlichota@ur.edu.pl (W.L.)

* Correspondence: annakowal@ur.edu.pl

\begin{abstract}
The article presents selected Polish early warning models (logit and discriminant models) that allow the assessment of the risk of bankruptcy of a company, and the purpose of the considerations is to indicate their prognostic effectiveness in predicting susceptible Polish companies one year before their declarations of bankruptcy. The limitations of these methods were also indicated in unpredictable situations, such as the outbreak of an economic crisis, e.g., caused by a humanitarian crisis-the COVID-19 pandemic. Another aim chosen in the article is a methodological critical assessment of the phenomenon of widespread use of foreign models (including the common Altman method) in the study of the risk of bankruptcy of Polish enterprises. Models developed on a sample of foreign enterprises without prior adaptation to domestic conditions are used all over the world, so the conclusions of the article are applicable internationally. The research was based on a query of Polish and foreign literature in the field of economic and legal aspects of bankruptcy and financial analysis, including, in particular, bankruptcy forecasting. The empirical research analyzes the financial data of 50 Polish enterprises from 2017 to 2018. The effectiveness of the selected bankruptcy forecasting models in identifying enterprises from section $\mathrm{C}$ of the Polish economy (industrial processing) that filed for bankruptcy in 2018 and 2019 was tested. The time frame fully allows for the identification and the assessment of the effectiveness of early warning models a year before bankruptcy.
\end{abstract}

Keywords: bankruptcy risk; early warning models; company bankruptcy; discriminant analysis; logit analysis

\section{Introduction}

As stated by Joseph A. Schumpeter [1], one of the most powerful mechanisms of economic progress is the so-called creative destruction-a phenomenon in which the bankruptcy of enterprises is an integral part. This phenomenon can be considered natural, as it acts as a means of natural selection [2]. In dynamic and competitive market conditions, every business is exposed to greater or lesser risk [3,4]. From the theoretical point of view, the bankruptcy of an enterprise is part of a self-regulatory market mechanism and may be a condition for market development; however, when considered in terms of the interest of the enterprises, it becomes an unfavorable phenomenon [5]. Creditors, managers, shareholders, investors, employees, and even the local community or the economy of a given country suffer major consequences [6-8]. In particular, creditors and suppliers are at risk when debtors go bankrupt because: "failure to fulfill debt commitments by a customer may hamper the solvency of the supplier (creditors), who may become unable in turn to pay its own suppliers located in the upper level, which may lead to a chain of similar failures (domino effect) and in extreme cases result in bankruptcy avalanches" [9]. At the same time, the stronger the ties between the attacked enterprise and other domestic and foreign partners, the faster the "bankruptcy virus" spreads. Globalization intensifies the diffusion of bankruptcies. It is no coincidence, therefore, that they are escalating globally (both in absolute and relative terms) [2]. 
Studies of the European Commission, suggest quite a radical thesis, which is often mentioned in the literature, stating that about $50 \%$ of enterprises registered in the European Union are not able to survive their first five years, and the percentage of bankruptcies among the enterprises that close in that time frame is around $15 \%[10,11]$. With increased financial globalization, faster economic changes, and a new dimension of increased financial risk in the context of the 2007 global financial crisis and the economic crisis caused by the COVID-19 pandemic, the question should not focus on whether bankruptcy prediction models should be used but rather on how to increase their effectiveness [12].

The article presents selected Polish early warning models (logit and discriminant models) that allow the assessment of the risk of enterprise bankruptcy, and the purpose of the considerations is to indicate their prognostic effectiveness in predicting susceptible Polish enterprises a year before their declarations of bankruptcy. The main criterion for determining a given enterprise as bankrupt was the submission of a bankruptcy petition to the territorially competent economic division (KRS) in the district court. Another purpose of the article is a methodological critical assessment of the phenomenon of widespread use of foreign models (including the popular Altman method) in the study of the risk of bankruptcy of Polish enterprises. The use of such models without prior adaptation to national conditions is common in many countries.

The research was based on a query of Polish and foreign literature in the field of economic and legal aspects of bankruptcy and a financial analysis regarding bankruptcy forecasting. The financial data of 50 Polish companies from 2017 to 2018 were used for empirical research. What was evaluated was the effectiveness of selected bankruptcy forecasting models in identifying enterprises from section $C$ of the Polish economy (industrial processing) that filed for bankruptcy in 2018 and 2019. The time frame fully allows for the identification and assessment of the effectiveness of early warning models a year before bankruptcy. In relation to the objectives of the study, two research hypotheses were formulated and verified:

Hypothesis 1 (H1). Despite the lapse of time, certain discriminatory and logit models show similar effectiveness of bankruptcy prediction to that indicated by their creators on the learning sample.

Hypothesis 2 (H2). The mechanical transfer of the Altman model (a model developed on a sample of American enterprises) onto the assessment of the risk of bankruptcy of Polish enterprises is not methodologically correct and generally does not bring reliable results.

\section{Review of the Literature}

Business bankruptcy is a polysemantic concept that is associated with many related terms, including financial failure, insolvency, loss of payment capacity, execution, liquidation, legal proceedings, coercion, deprivation of rights, and even the consequences of a financial or organizational crisis $[13,14]$. This phenomenon is defined both in a legal and an economic sense. In legal terms, it is a phenomenon of a legal institution established in order to stop a crisis situation in an enterprise by eliminating it from the market. From an economic point of view, bankruptcy is the failure of a company to meet its financial liabilities, combined with the lack of improvement prospects in terms of the entity's economic situation $[15,16]$. In Poland, bankruptcy is regulated by the Act of 28 February 2003, Bankruptcy Law [17]. According to its provisions, bankruptcy is declared in relation to a debtor who has become insolvent, that is, they have lost the ability to meet due pecuniary obligations or the pecuniary obligations exceeded the value of their assets [18].

It is worth emphasizing that the bankruptcy of an enterprise is preceded by a number of causes or symptoms of an internal (endogenous, which indicate the main reasons for the failure of a significant part of enterprises) and external (exogenous) nature [19]. The internal causes include the following [20,21]:

- $\quad$ poor financial policy leading to a high level of indebtedness, 
- loss of sales markets,

- lack of an unequivocally formed company strategy,

- too high debt, and

- insufficient financial control of concluded contracts.

The external causes are much more complex than the internal ones, as they are related to the country's situation-political, macroeconomic, and social, as well as to the internal situation of partners, investors, and clients. Internal and external causes differ in their predictability, as well as the intensity of the effects [22].

One of the tools in the process of assessing the economic and financial situation of an economic entity is undoubtedly the bankruptcy early warning system, which identifies the deteriorating financial standing and, in particular, detects elements that indicate a risk of bankruptcy. In the theory and practice of bankruptcy forecasting, a number of methods and types of predictive models (risk estimation models) have been formulated, the comprehensive classification of which was presented, among others, by McKee [23]. The assessment of bankruptcy risk is important primarily for managers when making decisions that contribute to improving the company's financial performance but also for investors considering a given company, as well as for creditors [24].

The first studies on bankruptcy prediction appeared in the United States [25]. Fitzpatrick identified significant differences between financially sound and distressed companies $[26,27]$. Since then, the use of bankruptcy prediction models has been widespread in developed economies. Many international researchers have tried to find an appropriate model for predicting bankruptcy using various methods in order to achieve the best prediction accuracy [28]. After the 2008 global financial crisis, the importance of predicting bankruptcy was confirmed and sparked a new wave of interest [29].

One of the most common methods is discriminant analysis. The issue of discrimination was first raised by Ronald A. Fisher [30]. In his work, he introduced the concept of the discriminant function and the method of estimating its parameters. The literature on the ideas, the formalization, and applications of Fisher's linear discriminant function is extensive. Its detailed description can be found in the works of Cornfield [31], Maddala [32], Mika et al. [33], Jajuga [34], etc. The development of discriminatory models of bankruptcy forecasting was largely due to Beaver [35], who was the first to apply onedimensional discriminant analysis. A breakthrough in the research area was the work of an American economist Edward Altman [36], who presented the possibility of using multidimensional linear discriminant analysis to build a model for assessing the risk of enterprises' bankruptcy.

In the 1970s, many authors used models built on a game theory to forecast the bankruptcy of enterprises. In the second half of the 1970s and at the beginning of the 1980s, the first logit and probit analyses appeared in the studies in the field of forecasting enterprise bankruptcy [37]. Compared with the Western countries, in post-socialist states, research on the subject became possible more than 20 years later. However, based on the historical development of corporate bankruptcy forecasting, it can be seen that it has already caught up with the best international practice [38].

In Poland, Maczyńska [39] was the first to use linear discriminant analysis to predict the bankruptcy of enterprises, while adapting the assumptions of Jacobs [40] to Polish economic conditions [41]. In the following years, early warning models appeared, prepared by Pogodzińska and Sojak [42], Gajdka and Stos [43], Hadasik [44], and Hołda [45].

The main goal of discriminant analysis is to classify an object into one of the distinguished groups according to a specific classification factor. When examining the risk of enterprises' bankruptcy, usually, there are only two groups considered-entities not at risk of bankruptcy and entities at risk of bankruptcy. The problem is to find a classification rule that will allow for the correct classification of companies described with diagnostic 
variables (financial ratios) into one of the groups [46]. The linear discriminant function proposed by Fisher is as follows [47]:

$$
D(X)=\alpha_{0}+a_{1} X_{1}+\alpha_{2} X_{2}+\ldots+a_{k} X_{k}
$$

where

$X$-vector of independent (explanatory) variables-in the case of bankruptcy forecasting models, these are most often financial indicators;

$\alpha_{0}$-constant of the discriminant function; and

$\alpha_{1}$-coefficients (weights) of the discriminant function.

The statistic characterizing the general discriminant ability of the function is the Wilks lambda coefficient, which has a value in the range $<0.1>$. When this value is closer to zero, it indicates a high discriminant ability of the model. The most important issue is to ensure the accuracy of the classification of the units surveyed by the model. For this purpose, a classification matrix is used to compare the classification of objects on the basis of a discriminant function with their actual belonging to the appropriate group. From a practical point of view, the construction and use of the discriminant function makes sense only when the accuracy of the classifications obtained on its basis is (in a statistical sense) significantly higher than in the case of the random allocation of statistical units to a given group [48].

The logit model is the second bankruptcy prediction tool commonly used in practice. The first researcher to use the logit model for this purpose was Ohlson [49]. The variables for this model were selected on the basis of the indicated literature in the field of financial analysis. Since then, there has been a rapid development of the use of logit models for the purposes of estimating bankruptcy risk [50]. Among the many publications on the subject, the work of Zavgren [51] should be mentioned as it estimates the logit function on the basis of 45 companies that went bankrupt and 45 companies in a "safe financial situation". Another interesting example of the use of the logit function is the work of H.D. Platt and M.B. Platt [52].

Logit models for forecasting the bankruptcy of Polish enterprises have been used since the beginning of the 21st century [50]. One of the first logit models was estimated by Hołda [53]. Gruszczyński also presented extensive research. Using an expert method, he selected 23 enterprises with a good financial standing and 23 enterprises with a bad financial condition. The learning sample separated in this way was used to build logit binomial models. By selecting a 25-element group of enterprises with an unclear financial situation, Gruszczyński estimated the trinomial logit models [54]. Wędzki also presented a number of logit models of bankruptcy in the Polish economy, including a multi-branch model for industrial enterprises [55]. The presented Polish logit models are only examples of Polish bankruptcy forecasting structures. Their detailed review can be found in the work by Prusak [56].

The logit model belongs to the class of binary models in which the dependent variable takes only two values, 1 with the probability $p_{i}$ and the value 0 with the probability $1-p_{i}$ presented as follows [47]:

$$
P\left(y_{i}=1\right)=p_{i}, P\left(y_{i}=0\right)=1-p_{i} .
$$

The probability is a function of the vector of explanatory variables $x_{i}$ and the vector of parameters $\beta$, therefore,

$$
p_{i}=P\left(y_{i}=1\right)=F\left(x_{i}^{T} \beta\right) \text { for } i=1,2, \ldots n .
$$


The values of the inverse function of $F$ are called logits. Logit is the logarithm of the odds of an event happening and not happening. It is determined from the dependence

$$
F^{-1}\left(p_{i}\right)=\ln \frac{p_{i}}{1-p_{i}} .
$$

In relation to the discussed issue, the logit is, therefore, the logarithm of the ratio of the odds of bankruptcy and "non-bankruptcy" of the enterprise. If the odds are the same, i.e., $p=0.5$, then logit is 0 , for $p>0.5$ the logit is positive, and for $p<0.5 \operatorname{logit}$ is negative.

After the logit transformation, one can proceed to study the relationship between logit values and explanatory variables being the appropriate financial indicators, usually adopting a linear econometric model of the form given below [57]:

$$
L=\beta_{0}+\beta_{1} X_{1}+\ldots+\beta_{k} X_{k}+\varepsilon .
$$

For many years, it has been discussed in the subject literature to define the impact of the number of model coefficients on its quality. More than once, studies have shown that the number of variables in a discriminant model is not a factor determining its quality [58]. According to Mączyńska and Zawadzki, a model with a dozen or so variables does not show a spectacularly higher classification accuracy than models with a smaller number of variables [2]. Korol also rejected the hypothesis that the use of more financial ratios increases the effectiveness of the bankruptcy forecasting model [59]. The Greek researcher Sfakianakis put forward a hypothesis that one properly selected index can determine the quality of a given model [60].

Puagwatana and Gunawardana presented a different opinion by presenting a logistic regression model for predicting business failures in the technology industry in Thailand [61]. The authors found that one way to improve the model is to add more coefficients, which will make the predictability of bankruptcy more accurate. The thesis about the greater effectiveness of the logit model with a greater number of coefficients was refuted by Lichota after researching Polish enterprises [57].

Moreover, Puagwatana and Gunawardana indicated that, when constructing the model, the existing macroeconomic conditions should be taken into account [61]. A similar position was taken by Slovak scientists who stated that the logistic regression model should include information about the size of the enterprise, as it is a significant predictor of the probability of financial difficulties [62]. From a methodological point of view, it seems particularly important to include the criterion of the enterprise specificity and the variable economic conditions of its operations in synthetic methods of assessing the financial condition of an enterprise [63-65].

The limitations of these two bankruptcy prediction methods should also be mentioned. The models of discriminant and logit analysis do not take into account factors influencing the activity of enterprises, such as development opportunities, moods among employees, the company's position on the market, or the quality of management [66]. Of course, they do not work in unpredictable situations, such as the outbreak of an economic crisis, e.g., caused by a humanitarian crisis-the COVID-19 pandemic. Many companies across the EU became defaulted due to lockdowns in 2020 and 2021 [67] — discriminatory and logit models based on financial data for obvious reasons did not indicate the risk of bankruptcy a year before the event.

It is also commonly expressed that the mechanical transfer of foreign models (models developed on a sample of foreign enterprises) onto the assessment of the financial condition of enterprises from another country is not methodologically correct $[2,68]$. At the same time, what should be supported is the hypothesis concerning the need for an earlier adaptation of a foreign model to the conditions of a given economy. The indiscriminate use of the current model with its original assumptions does not bring reliable results $[69,70]$. This position was taken by Hungarian researchers [38], who do not recommend applying bankruptcy models that have been developed on samples of foreign companies to Hungarian companies, 
regardless of their popularity and high citation. The results are consistent with those of Serbian researchers [71-76], who prove that the existing predictive models (e.g., Altmans's Z-score, model, Taffler's Z-score model, Sandin and Porporato's model, Zmijewski's model) are not accurate in predicting the bankruptcy of Serbian enterprises because the socioeconomic, institutional, and other operating conditions are significantly different than the ones in the countries where these models were developed. The Polish researcher Kitowski puts forward a blunt conclusion that "it is unacceptable, from a methodological point of view, to unauthorized modification of the most important assumptions (still known as the Altman method) and to uncritically recommend the use of this method to assess the risk of bankruptcy of Polish enterprises and to "fetish" its timeless diagnostic credibility and industry universality" [77]. Micherda [78] took a similar position.

In line with the aim of the article and the hypothesis put forward, the considerations focus on the Altman method, which is the most popular foreign method used in Polish economic practice. It is also used by statutory auditors in the process of auditing financial statements. Out of 100 randomly selected opinions, the E. Altman method was used in 82 cases to assess the risk of bankruptcy of the audited entity, including 39 cases using only this method (in 28, the E. Altman method and A. Hołda's method; in 11 opinions, the E. Altman method, the method of A. Hołda, and the method of M. Hamrol; and in 4 opinions, the method of E. Altman and the method of J. Gajdka and D. Stos) [77]. The national literature on the subject emphasizes that the results of the conducted research indicate the inadequacy of the Altman model to Polish conditions [78]. A similar position was taken by M. Hamrol, who believes that "it is difficult to imagine, for example, the use of the Altman model in a health care institution in assessing the risk of bankruptcy" [79].

This article notes that the Altman model is not only used for research purposes in Poland. The model is used in practice, with numerous errors and simplifications, which is not methodologically correct. Statutory auditors persistently use E. Altman's model, among others, to assess the financial condition of hospitals, and to make matters worse, they use the version of the model from 1968, intended for companies from the stock exchange (apart from the obvious fact that these hospitals are not joint stock companies). Particularly disturbing, from a methodological point of view, is the manner in which statutory auditors use the scheme for applying the version of the Altman method intended for unlisted jointstock companies. In their opinions of the financial statements of the audited companies, statutory auditors uncritically duplicate errors and methodological simplifications from the literature on the subject. For example, in the opinion of the auditor, the 1968 model of the method was used for a company listed on the Warsaw Stock Exchange but with many errors. In the analyzed reports of statutory auditors, we also find errors in the cases of using E. Altman's EM-Score model (without the asset turnover ratio). Until 2015, the State Fund for Rehabilitation of Disabled Persons verified the financial condition of entities applying for subsidies for the remuneration of employees with disabilities using the E. Altman method.

In the Polish literature on the subject, the topics of methodological controversies related to the use of the E. Altman model by statutory auditors and court experts are sporadically discussed, in different judicial decisions. The analysis of court judgments containing the assessment of the reliability of E. Altman's method leads to unexpected and contradictory conclusions. The proposed direction of research seems to be of great practical utility, as it is critical of the unilateral and uncritical application of discriminatory methods (especially the Altman model) by certified statutory auditors and court experts. It is amazing that, in the Polish literature on the subject, until 2015, it was not possible to find even one example of a correct discussion of the assumptions of the ZETA Score method, published by E. Altman, R. Haldeman, and P. Narayanan in 1977 [80].

Despite the presented limitations and controversies, the discriminant and logit models are characterized by objectivity, high prediction efficiency (if selected correctly), and simplicity resulting from the limitation of the method to the most important indicators [81,82]. When used correctly, the indicators enable the comparison of the financial situation of 
various enterprises, as well as the assessment of the risk of bankruptcy. The advantages also include transparency and ease of interpretation of the outcomes [83].

Polish enterprises do not use modern bankruptcy forecasting methods [84]. Moreover, statutory auditors do not fully use the tools of modern financial analysis. In Poland, despite the fact that logit models and classification trees give more accurate diagnoses, discriminatory models still dominate, and their number is nearly four times higher than the number of published logit models. Decision trees and neural networks are sporadically used in research into financial health risks.

\section{Materials and Methods}

The article verified 10 discriminant analysis models and 10 logistic regression models available in the national and international literature, based on the financial statements of 50 companies. The discriminant and logit models used in the article differ not only in the number of financial analysis indicators used but also in the period in which they were created, the number of entities that constituted the test group when estimating the parameters (often from a specific range of the value of assets or a specific sector) or the form of legal commercial company.

Due to the fact that early warning models should be used in the country of the establishment of a given enterprise, the sample included 19 models developed for the Polish economy and only one foreign model by E. Altman. The methods for the study were selected from a sample of several available methods in terms of their diagnostic reliability estimated by individual authors and their applicability for the industrial sector. The assumptions of the methods and indicators constituting the variables in the formulas have been described in scientific articles in accordance with the given bibliography.

The following discriminant functions were used:

1. Mączyńska, 1994 [39]

$$
Z=1.5 \cdot W_{1}+0.08 \cdot W_{2}+10.0 \cdot W_{3}+5.0 \cdot W_{4}+0.3 \cdot W_{5}+0.1 \cdot W_{6}
$$

$W_{1}$-(gross profit + amortization)/liabilities,

$W_{2}$-assets/liabilities,

$W_{3}$-gross profit/assets,

$W_{4}$-gross profit/revenues from sales,

$W_{5}$-inventory/revenues from sales, and

$W_{6}$-revenues from sales/assets.

2. Mączyńska and Zawadzki, 2006 [2]

$$
Z=9.478 \cdot W_{1}+3.613 \cdot W_{2}+3.246 \cdot W_{3}+0.455 \cdot W_{4}+0.802 \cdot W_{5}-2.478
$$

$W_{1}$-profit from operating activity/assets,

$W_{2}$ - equity/assets,

$W_{3}$-(net profit + amortization)/liabilities,

$W_{4}$-current assets/short-term liabilities, and

$W_{5}$-revenues from sales/assets.

3. Hamrol, Czajka, and Piechocki, 2004 [14]

$$
Z=3.562 \cdot W_{7}+1.588 \cdot W_{16}+4.288 \cdot W_{5}+6.719 \cdot W_{13}-2.368
$$

$W_{7}$-net profit/assets,

$W_{16}$-(current assets - inventory)/short-term liabilities,

$W_{5}$-(equity + long-term liabilities)/assets, and

$W_{13}$ - profit from sales/revenues from sales.

4. Hadasik, 1999 [44]

$$
Z=-1.3301 \cdot W_{5}+0.04094 \cdot W_{8}-0.0038 \cdot W_{12}+2.16525 \cdot W_{14}+0.0235 \cdot W_{17}+1.6238
$$


$W_{5}$-liabilities/assets,

$W_{8}$ - equity/tangible fixed assets,

$W_{12}$-inventory $\times 365 /$ revenues from sales,

$W_{14}$-net profit/assets, and

$W_{17}$-net profit/inventory.

5. Appenzeller, 2004 [85]

$$
Z=1.286 \cdot W_{1}-1.305 \cdot W_{2}-0.226 \cdot W_{3}+3.015 \cdot W_{4}-0.005 \cdot W_{5}-0.009 \cdot W_{6}-0.661
$$

$W_{1}$-current assets/short-term liabilities,

$\mathrm{W}_{2}$-(current assets - inventory - short-term receivables)/short-term liabilities,

$W_{3}$-gross profit/revenues from sales,

$W_{4}$-net profit/average assets,

$W_{5}$-average inventory $\times$ number of days/revenues from sales, and

$W_{6}$-liabilities/EBITDA.

6. Maślanka, 2008 [86]

$$
\begin{gathered}
Z=-1.44979+3.55401 \cdot W_{4}+2.14847 \cdot W_{6}-0.33302 \cdot W_{7}+4.81862 \cdot W_{17} \\
+0.05236 \cdot W_{26}+2.52164 \cdot W_{40}
\end{gathered}
$$

$W_{4}$-equity/assets,

$\mathrm{W}_{6}$ - net working capital/assets,

$W_{7}$-(equity + long-term liabilities)/fixed assets,

$W_{17}$ - profit from sales/assets,

$W_{26}$-revenues from sales/fixed assets, and

$W_{40}$-(profit from operating activity + amortization)/liabilities.

7. Prusak, 2004 [87]

$$
Z=6.9973 \cdot W_{1}+0.1191 \cdot W_{2}+0.1932 \cdot W_{3}-1.1760
$$

$W_{1}$ - profit from sales/average assets,

$\mathrm{W}_{2}$-operating costs/average short-term liabilities without special funds and shortterm financial liabilities, and

$W_{3}$-current assets/short-term liabilities.

8. Korol, 2010 [88]

$$
\begin{aligned}
& Z b=-1.97+2.35 \cdot W_{1}-2.90 \cdot W_{5}-2.68 \cdot W_{8}+0.79 \cdot W_{9} \\
& Z n=-3.49+9.93 \cdot W_{1}-0.05 \cdot W_{5}-0.62 \cdot W_{8}+1.19 \cdot W_{9}
\end{aligned}
$$

$W_{1}$ - profit from sales/assets,

$W_{5}$ - net working capital/assets,

$W_{8}$ - (net profit + amortization)/liabilities, and

$W_{9}$-operating costs/short-term liabilities.

9. Waszkowski, 2011 [89]

$$
Z=0.327 \cdot W_{1}+3.276 \cdot W_{2}+0.402 \cdot W_{3}-0.001 \cdot W_{4}+0.002 \cdot W_{5}-1.989
$$

$W_{1}$-revenues from sales/liabilities,

$W_{2}$-fixed assets/assets,

$W_{3}$-(net profit + amortization)/liabilities,

$\mathrm{W}_{4}$-revenues from sales/net working capital, and

$W_{5}$-net profit/revenues from sales. 
10. Altman, 1983 [90]

$$
Z=0.717 \cdot W_{1}+0.847 \cdot W_{2}+3.107 \cdot W_{3}+0.420 \cdot W_{4}+0.998 \cdot W_{5}
$$

$W_{1}$-working capital/assets,

$W_{2}$-retained earnings/assets,

$W_{3}$-EBIT/assets,

$W_{4}$-book value equity/liabilities, and

$W_{5}$-revenues from sales/assets.

The following logit models were used:

1. Korol, 2010 [88]

$$
Z=2.0-10.19 \cdot W_{1}-4.58 \cdot W_{2}-0.57 \cdot W_{3}
$$

$W_{1}$-profit from sales/assets,

$W_{2}$-(net profit + amortization)/liabilities, and

$W_{3}$-operating costs/short-term liabilities.

2. Wędzki, 2005—model 1 [55]

$$
Z=1.0-W_{1}-0.256 \cdot W_{2}-0.044 \cdot W_{3}-4.373 \cdot W_{4}
$$

$W_{1}$-current assets/short-term liabilities,

$W_{2}$-interest/(gross profit + interest),

$W_{3}$-profit from sales/assets, and

$W_{4}$ - gross profit/profit from sales.

3. Wędzki, 2005-model 5 [55]

$$
Z=2.0-2.0 \cdot W_{1}-0.323 \cdot W_{2}
$$

$W_{1}$-current assets/short-term liabilities and

$W_{2}$-interest/(gross profit + interest).

4. Wędzki, 2005-model 7 [55]

$$
Z=-4.0-6.0 \cdot W_{1}+9.37 \cdot W_{2}-2.088 \cdot W_{3}+1.317 \cdot W_{4}+0.04 \cdot W_{5}-4.217 \cdot W_{6}
$$

$W_{1}$-current assets/short-term liabilities,

$W_{2}$-liabilities/assets,

$W_{3}$-interest/(gross profit + interest),

$\mathrm{W}_{4}$-leverage index,

$W_{5}$-short-term receivables $\times$ number of days/revenues from sales, and

$W_{6}$ - profit from sales/revenues from sales.

5. Wędzki, 2005—model 8 [55]

$$
Z=-4.0-4.0 \cdot W_{1}+11.441 \cdot W_{2}-2.0 \cdot W_{3}
$$

$W_{1}$-current assets/short-term liabilities,

$W_{2}$-liabilities/assets, and

$W_{3}$-interest/(gross profit + interest).

6. Gruszczyński, 2003—model 3 [54]

$$
Z=22.8748 \cdot W_{1}-5.5926 \cdot W_{2}-26.1083 \cdot W_{3}+4.3515
$$

$W_{1}$-gross profit/revenues from sales,

$W_{2}$-liabilities/assets, and

$W_{3}$-inventory/revenues from sales. 
7. Gruszczyński, 2003—model 7 [54]

$$
Z=1.2458 \cdot W_{1}+13.1907 \cdot W_{2}-4.4523 \cdot W_{3}
$$

$W_{1}$-current assets/short-term liabilities,

$W_{2}$-profit from operating activity/assets, and

$W_{3}$-liabilities/assets.

8. Stępień and Strąk, 2004—model 1 [91]

$$
Z=-19-11 \cdot W_{1}+6 \cdot W_{2}+40 \cdot W_{3}+19 \cdot W_{4}
$$

$W_{1}$-liabilities/assets,

$W_{2}$-(current assets - inventory)/short-term liabilities,

$W_{3}$-profit from sales/assets, and

$W_{4}$-revenues from sales/operating costs.

9. Stępień and Strąk, 2004-model 2 [91]

$$
Z=5.83+4.27 \cdot W_{1}+2.00 \cdot W_{2}-7.78 \cdot W_{3}
$$

$W_{1}$-gross profit/assets,

$W_{2}$-net working capital/assets, and

$W_{3}$-liabilities/assets.

10. Hołda, 2006 [18]

$$
Z=1.659+16.609 \cdot W_{1}+2.442 \cdot W_{2}-5.40 \cdot W_{3}
$$

$W_{1}$-profit from sales/operating costs,

$W_{2}$-current assets/short-term liabilities, and

$W_{3}$-liabilities/assets.

\section{Results}

In Tables 1 and 2, the results of correct indications of the risk of bankruptcy of companies are presented using the discriminatory and logit models presented in the methods chapter. The research sample consisted of 50 industrial processing companies in Poland. The financial data of the companies were taken from the EMIS database and were included in the sample on the basis of the highest asset value criterion.

Table 1. Values of discriminant functions one year before the bankruptcy of individual enterprises.

\begin{tabular}{cccccccccccc}
\hline Company/Author & $\mathbf{1}$ & $\mathbf{2}$ & $\mathbf{3}$ & $\mathbf{4}$ & $\mathbf{5}$ & $\mathbf{6}$ & $\mathbf{7}$ & $\mathbf{8}$ & $\mathbf{9}$ & $\mathbf{1 0}$ \\
\hline 1 & -2.53 & -4.58 & -5.26 & -0.97 & -1.05 & -5.18 & -3.70 & 4.90 & 1.26 & 3.48 \\
\hline 2 & -5.50 & -4.79 & -8.77 & -4.78 & -5.62 & -3.94 & -3.24 & 3.76 & -1.26 & -3.04 \\
\hline 3 & -6.84 & -7.47 & -7.22 & -1.95 & -1.81 & -6.19 & -4.88 & 5.95 & -1.02 & -3.28 \\
\hline 4 & -27.42 & -16.20 & -48.27 & -4.37 & -2.25 & -14.69 & -9.75 & 13.03 & 0.11 & -12.19 \\
\hline 5 & -9.41 & -8.81 & -0.45 & -1.82 & -0.75 & -3.67 & -2.98 & 0.32 & -0.03 & 2.07 \\
\hline 6 & -9.68 & -9.01 & -6.57 & -2.03 & -2.03 & -5.04 & -5.20 & 5.92 & -0.96 & -0.45 \\
\hline 7 & -117.47 & -3.07 & -1.10 & -0.06 & 5.53 & -21.22 & -0.83 & 2.42 & -1.69 & -2.00 \\
\hline 8 & -248.00 & -4.12 & -1.34 & -0.72 & 11.13 & -7.75 & -8.06 & 8.42 & 1.89 & 3.17 \\
\hline 9 & -0.62 & 1.12 & -0.18 & 0.58 & 0.34 & 0.25 & -1.12 & 0.91 & 0.70 & 3.78 \\
\hline 10 & -9.32 & -6.16 & -8.82 & -7.88 & -2.55 & 2.54 & -5.62 & 5.92 & -1.02 & -0.51 \\
\hline
\end{tabular}


Table 1. Cont.

\begin{tabular}{|c|c|c|c|c|c|c|c|c|c|c|}
\hline Company/Author & 1 & 2 & 3 & 4 & 5 & 6 & 7 & 8 & 9 & 10 \\
\hline 11 & -85.84 & -93.26 & -57.36 & -23.66 & -22.33 & -45.78 & -43.58 & 35.50 & 0.77 & -39.94 \\
\hline 12 & -3.83 & -4.59 & -3.69 & -0.80 & -0.80 & -3.21 & -3.70 & 3.54 & -1.08 & 0.46 \\
\hline 13 & -3.53 & -3.95 & 4.63 & -177.45 & -1.16 & -4.92 & -5.51 & 6.43 & -1.46 & -3.47 \\
\hline 14 & -2.32 & -4.58 & -0.64 & -0.92 & -0.92 & -4.26 & -1.38 & 2.15 & 1.26 & -1.47 \\
\hline 15 & -24.58 & -64.90 & -113.20 & -175.59 & -196.34 & -16.03 & -12.90 & 19.89 & -1.90 & -66.05 \\
\hline 16 & -9.53 & -4.91 & -5.66 & -25.72 & -0.71 & -5.54 & -2.18 & 4.46 & 1.20 & -4.64 \\
\hline 17 & -16.38 & -7.16 & -14.99 & -1.99 & -1.70 & -1.84 & -4.56 & 4.48 & -2.01 & -0.97 \\
\hline 18 & -12.17 & -10.34 & -8.61 & -1.22 & -2.26 & -6.88 & -6.48 & 8.36 & -0.32 & 0.32 \\
\hline 19 & -9.71 & -5.83 & -15.01 & -1.73 & -1.54 & -5.46 & -4.07 & 5.33 & -0.79 & -3.81 \\
\hline 20 & 9.84 & -12.57 & 5.79 & -3.09 & -1.55 & -12.64 & -5.06 & 7.03 & -0.47 & -10.90 \\
\hline 21 & -7.24 & -10.72 & -12.75 & -3.48 & -2.47 & -15.87 & -9.81 & 13.62 & 1.91 & -6.23 \\
\hline 22 & -2.02 & -82.79 & -101.54 & -30.10 & -1.85 & -111.12 & -39.64 & 66.35 & -0.63 & -136.33 \\
\hline 23 & -13.81 & -10.79 & -29.54 & -5.03 & -3.68 & -12.21 & -6.35 & 9.23 & -0.77 & -12.85 \\
\hline 24 & -4.64 & -58.12 & -66.94 & -20.16 & -0.20 & -19.37 & -2.91 & 2.45 & -1.54 & -38.43 \\
\hline 25 & 0.29 & -0.58 & 1.08 & 0.17 & -0.90 & -0.67 & -0.89 & 1.17 & 0.39 & 0.93 \\
\hline 26 & -2692.1 & -10.41 & -3212.4 & -1.86 & 119.51 & -8.67 & -6.25 & 6.91 & -3.16 & -5.06 \\
\hline 27 & -6860.2 & -138.86 & -154.97 & -39.85 & 284.24 & 752.25 & -58.56 & 54.87 & -4.83 & -115.56 \\
\hline 28 & -46.80 & -78.85 & -70.70 & -25.23 & -14.14 & 1982.7 & -52.56 & 66.41 & -1.86 & -62.49 \\
\hline 29 & -3.73 & -4.14 & -3.45 & -9.99 & -0.71 & -4.06 & -4.07 & 4.04 & -0.28 & 1.39 \\
\hline 30 & -0.52 & -0.54 & -1.07 & 0.26 & 0.01 & -1.26 & -1.81 & 1.36 & -0.20 & 2.17 \\
\hline 31 & -9.50 & -13.35 & -10.51 & -3.85 & -2.83 & -3.99 & -7.31 & 7.70 & -1.81 & -5.16 \\
\hline 32 & 1.85 & 1.85 & -2.17 & -0.07 & 0.26 & -2.42 & -1.86 & 1.55 & -1.22 & 3.45 \\
\hline 33 & -10.13 & -10.63 & -8.21 & -3.12 & -2.99 & -9.76 & -9.05 & 9.77 & -0.34 & 1.03 \\
\hline 34 & -4.95 & -3.94 & -2.71 & -0.38 & -0.68 & -2.76 & -3.57 & 3.26 & -0.53 & 3.57 \\
\hline 35 & -5.61 & -5.78 & -4.03 & -1.01 & -1.39 & -2.05 & -3.85 & 3.26 & -1.06 & 1.30 \\
\hline 36 & -30.47 & -7.16 & -70.42 & -9.64 & -10.61 & -6.69 & -4.30 & 5.82 & -0.55 & -4.89 \\
\hline 37 & -1.46 & -1.08 & -0.91 & 0.23 & -0.13 & -1.09 & -1.52 & 0.97 & 0.48 & 2.09 \\
\hline 38 & -0.37 & 0.33 & -0.75 & 0.40 & -0.06 & -1.08 & -1.38 & 0.86 & 0.64 & 2.60 \\
\hline 39 & -0.18 & -1.87 & -204.53 & 0.21 & -0.57 & -2.02 & -1.37 & 2.73 & 0.74 & -0.44 \\
\hline 40 & -19.45 & -6.58 & -18.82 & -6.95 & -5.95 & -9.16 & -5.64 & 8.62 & -0.85 & -8.62 \\
\hline 41 & -3.45 & -1.96 & -4.75 & -0.90 & -0.47 & 3.63 & -2.64 & 2.84 & -1.52 & 1.38 \\
\hline 42 & 0.44 & -0.96 & -2.18 & 0.21 & -0.50 & -1.48 & -1.87 & 1.52 & -0.81 & 0.50 \\
\hline 43 & -2.38 & -1.29 & -0.35 & 0.83 & -0.22 & -2.08 & -1.09 & 1.34 & 0.60 & 1.21 \\
\hline 44 & 0.40 & -1.50 & 0.37 & -0.47 & 0.07 & -1.55 & -0.65 & 0.65 & 0.50 & 0.39 \\
\hline 45 & -5.40 & -7.30 & -10.42 & -3.02 & -1.95 & -12.14 & -5.35 & 9.55 & 0.40 & -9.17 \\
\hline 46 & -4.96 & -4.93 & -8.98 & -1.86 & -1.77 & -7.76 & -4.25 & 7.47 & 0.07 & -6.22 \\
\hline 47 & -7.17 & -12.45 & -14.64 & -6.29 & -2.57 & -20.89 & -6.96 & 12.10 & 0.21 & -13.19 \\
\hline 48 & 0.57 & -0.29 & 1.25 & 0.62 & 0.67 & -0.35 & -1.07 & 0.68 & -0.44 & 1.61 \\
\hline 49 & 16.41 & 13.22 & 1.81 & 2.82 & 3.01 & 8.57 & 3.73 & -14.49 & 3.35 & 11.50 \\
\hline 50 & 0.68 & 2.47 & 3.99 & 0.88 & 2.66 & 1.78 & -0.20 & -1.16 & 0.71 & 3.97 \\
\hline
\end{tabular}


Table 2. Values of logit models one year before the bankruptcy of individual enterprises.

\begin{tabular}{|c|c|c|c|c|c|c|c|c|c|c|}
\hline Company/Author & 1 & 2 & 3 & 4 & 5 & 6 & 7 & 8 & 9 & 10 \\
\hline 1 & 1.27 & 7.34 & 10.58 & -11.39 & -7.86 & -22.34 & -7.46 & -6.85 & -2.36 & -0.14 \\
\hline 2 & 2.82 & 4.92 & 0.89 & 27.27 & 9.68 & -107.10 & -6.85 & -15.70 & -6.69 & -11.13 \\
\hline 3 & 5.40 & 1.82 & 1.06 & 14.26 & 13.76 & -12.28 & -10.98 & -27.99 & -11.25 & -8.58 \\
\hline 4 & 9.36 & 17.69 & 1.74 & 63.00 & 24.92 & -101.59 & -21.61 & -66.10 & -22.02 & -25.94 \\
\hline 5 & 1.93 & 0.82 & -1.31 & -7.63 & 3.03 & -12.00 & -11.87 & -12.57 & -6.00 & -1.77 \\
\hline 6 & 7.99 & 3.03 & 0.61 & -25.25 & 5.21 & -17.88 & -11.11 & -26.76 & -5.35 & -6.93 \\
\hline 7 & 3.21 & 103.08 & 0.57 & 74.28 & 7.46 & -540.35 & -4.68 & -32.41 & -3.91 & -98.25 \\
\hline 8 & 16.41 & 215.99 & -1.92 & 210.69 & 7.69 & -1140.0 & -5.16 & -82.34 & -4.76 & -94.68 \\
\hline 9 & 1.60 & -0.10 & -0.43 & -2.46 & -3.20 & -4.62 & -0.66 & 4.00 & 1.97 & 0.92 \\
\hline 10 & 4.91 & 0.94 & 1.04 & 12.20 & 16.08 & -9.83 & -13.07 & -29.21 & -14.60 & -8.20 \\
\hline 11 & 23.30 & 10.59 & 1.98 & 64.10 & 76.37 & -85.89 & -126.36 & -150.29 & -93.90 & -41.86 \\
\hline 12 & 4.29 & 0.92 & 0.42 & -7.63 & 5.43 & -10.76 & -7.48 & -19.30 & -4.33 & -4.20 \\
\hline 13 & 3.62 & 1.33 & 1.23 & 1241.4 & 1526.5 & -753.52 & -599.29 & -1481.7 & -1039.7 & -722.36 \\
\hline 14 & 1.65 & 1.69 & 1.83 & 5.79 & 12.51 & -8.25 & -7.61 & -18.65 & -6.59 & -6.80 \\
\hline 15 & 2.37 & 51.01 & 1.74 & 2387.0 & 203.72 & -3238.5 & -81.33 & -218.58 & -148.63 & -112.92 \\
\hline 16 & 2.54 & 9.30 & 3.47 & 10.68 & 23.12 & -41.65 & -7.33 & -21.73 & -8.69 & -11.90 \\
\hline 17 & 5.94 & 10.91 & 0.30 & 62.32 & 5.71 & -80.32 & -9.03 & -30.84 & -5.06 & -12.93 \\
\hline 18 & 11.94 & 3.72 & 0.57 & 13.07 & 2.44 & -22.23 & -12.11 & -42.69 & -3.92 & -8.34 \\
\hline 19 & 4.25 & 7.56 & 1.12 & 81.36 & 10.60 & -58.60 & -8.20 & -32.35 & -6.89 & -15.21 \\
\hline 20 & 4.01 & -9.80 & 1.46 & -57.73 & 31.42 & 41.64 & -16.68 & -80.42 & -21.87 & -50.36 \\
\hline 21 & 10.14 & 1.10 & 1.66 & 20.21 & 25.93 & -14.68 & -20.28 & -64.25 & -22.34 & -14.50 \\
\hline 22 & 2.95 & 2.20 & 1.95 & 233.76 & 260.10 & -131.24 & -103.65 & -261.40 & -218.84 & -127.89 \\
\hline 23 & 3.82 & 11.93 & 1.57 & 37.69 & 28.04 & -116.24 & -14.63 & -50.57 & -21.05 & -25.59 \\
\hline 24 & 2.04 & 3.04 & 0.54 & 185.19 & 177.69 & -100.40 & -72.95 & -160.76 & -120.34 & -84.40 \\
\hline 25 & 1.25 & 0.12 & 0.23 & 2.06 & 0.80 & -10.60 & -2.12 & -4.83 & 0.07 & -0.10 \\
\hline 26 & 6.90 & 2350.8 & 0.84 & 2773.5 & 15.47 & -12.30 & -13.57 & -52.03 & -10.43 & -23.82 \\
\hline 27 & 4.11 & 5936.8 & 1.90 & 2837.3 & 217.02 & -31.15 & -181.98 & -230.28 & -181.30 & -119.24 \\
\hline 28 & 45.48 & 2.37 & 1.85 & 115.93 & 139.60 & -76.80 & -113.99 & -310.30 & -115.16 & -70.82 \\
\hline 29 & 4.51 & 0.66 & 0.65 & -5.50 & 6.17 & -4.33 & -8.39 & -21.60 & -4.88 & -4.23 \\
\hline 30 & 1.60 & 0.19 & 0.22 & 8.47 & 1.71 & -5.42 & -3.15 & -8.83 & -0.65 & -0.98 \\
\hline 31 & 8.07 & 2.82 & 0.86 & 17.29 & 21.46 & -36.83 & -18.50 & -53.18 & -17.24 & -15.16 \\
\hline 32 & 2.92 & -0.82 & -0.98 & -0.08 & -1.33 & -13.92 & -0.03 & -16.38 & 0.79 & -2.08 \\
\hline 33 & 10.73 & 0.88 & 1.10 & 11.60 & 16.25 & -10.56 & -20.21 & -58.60 & -14.75 & -9.64 \\
\hline 34 & 5.81 & 0.47 & -0.54 & 0.03 & -1.86 & -10.86 & -5.78 & -21.18 & -0.25 & -1.15 \\
\hline 35 & 3.89 & 0.89 & 0.60 & -7.19 & 5.92 & -7.30 & -9.81 & -16.99 & -5.30 & -3.55 \\
\hline 36 & 4.66 & 26.74 & 1.24 & 132.21 & 13.49 & -301.57 & -9.80 & -40.97 & -9.81 & -22.68 \\
\hline 37 & 0.86 & 0.46 & 0.49 & 8.56 & 2.05 & -1.71 & -3.88 & -4.88 & -0.95 & -0.64 \\
\hline 38 & 0.47 & 0.46 & 0.74 & 13.42 & 3.65 & -3.75 & -2.89 & -7.38 & -0.73 & -0.93 \\
\hline 39 & 2.75 & 1.08 & 1.45 & 171.13 & 6.56 & -12.14 & -3.51 & -0.85 & -1.66 & -18.20 \\
\hline 40 & 2.90 & 1.54 & 1.60 & 26.21 & 33.58 & -21.73 & -14.62 & -38.00 & -33.21 & -15.86 \\
\hline
\end{tabular}


Table 2. Cont.

\begin{tabular}{ccccccccccccc}
\hline Company/Author & $\mathbf{1}$ & $\mathbf{2}$ & $\mathbf{3}$ & $\mathbf{4}$ & $\mathbf{5}$ & $\mathbf{6}$ & $\mathbf{7}$ & $\mathbf{8}$ & $\mathbf{9}$ & $\mathbf{1 0}$ \\
\hline 41 & 4.21 & 0.49 & -0.07 & -1.02 & 6.24 & -10.23 & -7.67 & -23.78 & -5.01 & -4.51 \\
\hline 42 & 1.08 & 0.02 & 0.27 & 35.71 & 3.10 & -13.03 & -3.34 & -10.24 & -2.22 & -1.65 \\
\hline 43 & 1.70 & 0.64 & 0.26 & 58.83 & 3.80 & -5.85 & -5.34 & -13.26 & -2.60 & -2.85 \\
\hline 44 & 0.52 & -0.21 & -0.14 & 0.72 & 2.85 & -6.98 & -3.32 & -1.97 & -2.62 & -1.05 \\
\hline 45 & 6.05 & 1.96 & 1.70 & 20.34 & 25.17 & -20.69 & -16.85 & -48.45 & -19.78 & -15.47 \\
\hline 46 & 5.04 & 2.45 & 1.57 & 12.62 & 15.29 & -22.54 & -11.19 & -33.89 & -11.80 & -11.63 \\
\hline 47 & 7.06 & 1.28 & 1.74 & 40.37 & 49.79 & -26.27 & -28.89 & -74.97 & -38.80 & -25.26 \\
\hline 48 & 1.10 & -0.41 & -0.46 & 10.04 & -0.79 & -1.13 & -1.52 & -0.03 & 0.18 & 0.48 \\
\hline 49 & -23.74 & -0.78 & 0.37 & 58.17 & 3.72 & -0.08 & 14.94 & 40.61 & 2.77 & 0.29 \\
\hline 50 & -0.41 & -2.35 & -4.50 & -15.74 & -15.51 & -6.24 & 3.20 & 8.85 & 5.06 & 8.62 \\
\hline
\end{tabular}

Source: own study; explanation: the models are assigned in the table according to the numbering in Section 3.

The calculations presented in Table 3 show that the highest overall efficiency was presented by B. Prusak's model, 100\%; a slightly lower discriminant and logit model by T. Korol, $96 \%$ and $98 \%$; logit model 3 of M. Gruszczyński, $98 \%$ and model 7, 96\%; model 1 of Stępień and Strak, 94\%; A. Hołda's model, 92\%; and Mączyńska and Zawadzki's model, $90 \%$. It is worth noting that these models were constructed by the authors in the years 2003-2010, i.e., several years ago. Thus, it can be argued that the models do not lose their prediction capabilities over time. The average effectiveness was demonstrated by the models D. Appenzeller-78\%, E. Mączyńska-84\%, M. Hamrol—86\%, T. Maślanka$88 \%$, D. Wẹdzki, from $78 \%$ to $88 \%$, and Stepien and Strak $2-88 \%$. In turn, the lowest prognostic value was shown by Waszkowski's model, $62 \%$, which was the youngest in the research sample; E. Altman's model with correct indications at the level of $70 \%$; and D. Hadasik, $74 \%$.

Table 3. Efficiency of individual models.

\begin{tabular}{|c|c|c|c|c|c|c|c|c|c|c|}
\hline $\begin{array}{l}\text { Discriminant } \\
\text { Models/Author }\end{array}$ & 1 & 2 & 3 & 4 & 5 & 6 & 7 & 8 & 9 & 10 \\
\hline $\begin{array}{l}\text { Effectiveness according } \\
\text { to the authors }\end{array}$ & no data & $85 \%$ & $96 \%$ & $88 \%$ & $85 \%$ & $92 \%$ & $98 \%$ & $87 \%$ & $89 \%$ & no data \\
\hline $\begin{array}{l}\text { Effectiveness according } \\
\text { to the conducted study }\end{array}$ & $84 \%$ & $90 \%$ & $86 \%$ & $74 \%$ & $78 \%$ & $88 \%$ & $100 \%$ & $96 \%$ & $62 \%$ & $70 \%$ \\
\hline Logit Models/Author & 1 & 2 & 3 & 4 & 5 & 6 & 7 & 8 & 9 & 10 \\
\hline $\begin{array}{l}\text { Effectiveness according } \\
\text { to the authors }\end{array}$ & $93 \%$ & $69 \%$ & $69 \%$ & $74 \%$ & $78 \%$ & $93 \%$ & $97 \%$ & $80 \%$ & $84 \%$ & $82 \%$ \\
\hline $\begin{array}{l}\text { Effectiveness according } \\
\text { to the conducted study }\end{array}$ & $98 \%$ & $86 \%$ & $82 \%$ & $78 \%$ & $88 \%$ & $98 \%$ & $96 \%$ & $94 \%$ & $88 \%$ & $92 \%$ \\
\hline
\end{tabular}

Source: own study.

It should also be noted that the models were estimated on the basis of a certain group of companies from various industries and with a specific value of assets. Therefore, there may be a mismatch between the enterprise and the model, which makes it even more important to use several models to exclude such a possibility. When verifying the effectiveness of models, it is worth considering the reasons for the incorrect classification of a given enterprise. In the case of the sample in question, there may be a variety of reasons, for example: 
- $\quad$ some models constructed several years ago, in different economic conditions than today, may have lost their quality, but these are isolated cases in a research sample;

- the examined enterprise does not correspond to the test sample made by the author of the model in terms of the industry, revenues, or assets;

- the model was developed on the basis of a learning sample of enterprises from another country;

- $\quad$ the bankruptcy of the enterprise does not result from growing, long-term financial problems, but is the result of a specific, unforeseen factor, e.g., loss of the only recipient of the products or services.

When analyzing the three companies to which the models reacted the least. i.e., companies 9, 49, and 50, it should be noted that

- company no. 9 recorded a net loss of approximately EUR 150,000 while the other financial ratios, not taking into account the net result, were at the optimal level. Moreover, the company depreciated fixed assets in the amount of approximately EUR 70,000 , which meant that the ratios taking into account the net profit adjusted for depreciation had a lesser impact on the value of the function.

- company no. 49 lost liquidity due to two unprofitable investments. Moreover, the company's management board resigned, which started the company's problems.

- company no. 50 did not generate a net loss, but the costs of purchasing materials were very high. Operating expenses accounted for $98.5 \%$ of sales revenues, and activity became unprofitable.

\section{Conclusions}

The aim of the article was to verify the diagnostic reliability of selected discriminant and logit models, which are included in the early warning systems of the risk of enterprise bankruptcy. Moreover, the phenomenon of widespread use of foreign models was critically assessed, including in particular the Altman method in the study of the risk of bankruptcy of Polish enterprises. Foreign models without prior adaptation to domestic conditions are used not only in Polish economic practice but also by scientists, statutory auditors, and financial directors and managers in many countries. As it results from the review of the literature on the subject and the presented research, such an uncritical transfer of a foreign model with original assumptions does not bring reliable results. The same conclusions were made by E. Altman himself [92]. Altman's model verified on a research sample of Polish enterprises proved to be effective at the level of $70 \%$, and it was one of the lowest values; therefore, hypothesis $2(\mathrm{H} 2)$ was positively verified. Contradictory conclusions can be drawn especially from studies in which this method was incorrectly applied [70]. In this article, it was noted that the Altman model is not only used for research purposes in Poland. The model is used in practice, with numerous errors and simplifications, which is not methodologically correct.

On the basis of the obtained research results, it was also found that most of the models used in the article correctly indicated the risk of bankruptcy of enterprises, regardless of whether the model was developed a few or several years ago; thus, hypothesis 1 (H1) was positively verified. Due to the fact that some models accurately identified the risk of bankruptcy of all or almost all enterprises, e.g., the Prusak's, Korol's, Gruszczyński's model ( 3 and 7), and some of them incorrectly classified several surveyed enterprises, e.g., Waszkowski's model (19 out of 50). It is suggested to use as many discriminant and logit models as possible to assess the risk of bankruptcy, as well as other available methods of assessing the financial condition of the enterprise, e.g., risk scoring methods and traditional ratio analysis. For this reason, further research should be undertaken to verify the effectiveness of the prediction of the indicated methods.

When analyzing the models that were used to assess the financial situation of companies, it was determined that the selection of indicators that make up a given function is very important, e.g., the results of D. Hadasik's method depend in particular on changes in the level of inventories and receivables in a given year. Other authors, however, pay a 
lot of attention to indicators based on the operating result or the result of sales, assigning them sufficient significance. The weight of individual indicators is also important, e.g., an increase in the balance sheet total, which will cause a decrease in the overall debt ratio, while at the same time the high importance of this indicator means that the value of the discriminant function increases, in spite of the remaining indicators responding in the direction determined by other functions, i.e., reducing the value of the discriminant function. The mathematical sign applied to the indicator's weight is also important. In the case of the functions of D. Appenzeller and K. Szarzec, the subtraction of the "debt/EBITDA" ratio is justified, because the greater the debt, the worse the financial condition of the enterprise. On the other hand, in the case of an operating loss that cannot be covered by depreciation, the ratio is also negative. When performing mathematical calculations, it turns out that a significant operating loss increases the value of the discriminant function, and consequently, it can be concluded that the company's situation is improving [93].

Author Contributions: Conceptualization, J.K., A.K.-P. and W.L.; methodology, J.K., A.K.-P. and W.L.; validation, J.K., A.K.-P. and W.L.; formal analysis, J.K., A.K.-P. and W.L.; investigation, J.K., A.K.-P. and W.L.; writing and editing, J.K., A.K.-P. and W.L. All authors have read and agreed to the published version of the manuscript.

Funding: This research received no external funding.

Institutional Review Board Statement: Not applicable.

Informed Consent Statement: Informed consent was obtained from all subjects involved in the study.

Data Availability Statement: Not applicable.

Conflicts of Interest: The authors declare no conflict of interest.

\section{References}

1. Schumpeter, J.A. The Theory of Economic Development; Transaction Publishers: Piscataway, NJ, USA, 1982.

2. Mączyńska, E.; Zawadzki, M. Dyskryminacyjne modele predykcji upadłości przedsiębiorstw. Ekonomista 2006, 2, $205-235$.

3. Mackevičius, J.; Šneidere, R.; Tamulevičienè, D. The waves of enterprises bankruptcy and the factors that determine them: The case of Latvia and Lithuania. Int. J. Entrep. Sustain. Issues 2018, 6, 100-114. [CrossRef]

4. Horváthová, J.; Mokrišová, M. Risk of Bankruptcy, Its Determinants and Models. Risks 2018, 6, 117. [CrossRef]

5. Szymański, W. Globalizacja a proces kreacji i destrukcji przedsiębiorstw. In Zagrożenie Upadłością; Kuciński, K., Mączyńska, E., Eds.; Materiały i Prace Instytutu Funkcjonowania Gospodarki Narodowej. T. XCIII; Oficyna Wydawnicza SGH: Warszawa, Poland, 2005.

6. Rose-Ackerman, S. Risk taking and ruin: Bankruptcy and investment choice. J. Leg. Stud. 1991, 20, 277-310. [CrossRef]

7. Agustia, D.; Muhammad, N.P.A.; Permatasari, Y. Earnings management, business strategy, and bankruptcy risk: Evidence from Indonesia. Heliyon 2020, 6, e03317. [CrossRef] [PubMed]

8. Prusak, B. Review of Research into Enterprise Bankruptcy Prediction in Selected Central and Eastern European Countries. Intern. J. Financ. Stud. 2018, 6, 60. [CrossRef]

9. Battiston, S.; Gatti, D.D.; Gallegati, M.; Greenwald, B.; Stiglitz, J.E. Credit chains and bankruptcy propagation in production networks. J. Econ. Dyn. Control 2007, 31, 2061-2084. [CrossRef]

10. European Commission. Report of the Expert Group a Second Chance for Entrepreneurs: Prevention of Bankruptcy, Simplification of Bankruptcy Procedures and Support for a Fresh Start; European Commission: Brussels, Belgium, 2011.

11. European Commission. Business Dynamics: Start-Ups, Business Transfers and Bankruptcy "The Economic Impact of Legal and Administrative Procedures for Licensing, Business Transfers and Bankruptcy on Entrepreneurship in Europe"; Final Report; European Commission: Brussels, Belgium, 2011.

12. Korol, T. Dynamic Bankruptcy Prediction Models for European Enterprises. J. Risk Financ. Manag. 2019, 12, 185. [CrossRef]

13. Šverko Grdić, Z.; Radolović, J.; Bagarić, L. Solventnost poduzeća u Republici Hrvatskoj iu Europskoj uniji. Ekon. Preglowat 2009, $60,250-266$.

14. Hamrol, M.; Czajka, B.; Piechocki, M. Upadłość przedsiębiorstwa-model analizy dyskryminacyjnej. Przegląd Organ. 2004, 6, 35-39. [CrossRef]

15. Aleksanyan, L.; Huiban, J.P. Economic and Financial Determinants of Firm Bankruptcy: Evidence from the French Food Industry. Rev. Agric. Food Environ. Stud. 2016, 97, 89-108. [CrossRef]

16. Grzegorzewska, E. Zagrożenie upadłością a cykl życia przedsiębiorstw rolniczych. In Cykle Życia i Bankructwa Przedsiębiorstw; Mączyńska, E., Ed.; Oficyna Wydawnicza SGH: Warszawa, Poland, 2010; pp. 255-256. 
17. Ustawa z Dnia 28 Lutego 2003 r. Prawo upadłościowe [The Act of February 28, 2003, Bankruptcy Law]. Available online: http:/ / isap.sejm.gov.pl/isap.nsf/DocDetails.xsp?id=wdu20030600535 (accessed on 22 January 2022).

18. Hołda, A. Zasada Kontynuacji Działalności i Prognozowanie Upadłości w Polskich Realiach Gospodarczych; Seria Specjalna, Monografie; Zeszyty Naukowe/Akademia Ekonomiczna w Krakowie: Kraków, Poland, 2006.

19. Coughtrie, D.; Morley, J.; Ward, T. Restructuring in Bankruptcy: Recent National Case Examples; European Foundation for the Improvemenr of Living and Workin Coditions: Dublin, Ireland, 2009.

20. Kopczyński, P. Zastosowanie metod prognozowania upadłości opracowanych w krajach rozwijających się dla celów prognozowania upadłości polskich przedsiębiorstw. Studia Ekon. Reg. Łódzkiego 2016, 22, 221-239.

21. Ooghe, H.; De Prijcker, S. Failure process and causes of company bankruptcy: A typology. In Working Papers of Faculty of Economics and Business Administration; Ghent University: Ghent, Belgium, 2006; Volume 06, p. 388.

22. Banach-Kobyra, A. Prognozowanie upadłości przedsiębiorstw jako narzędzie monitorowania zaistnienia sytuacji kryzysowych. Przedsiębiorstwo We Wspótczesnej Gospod.-Teor. I Prakt. 2017, 3, 213-230.

23. McKee, T.E. Developing a Bankruptcy Prediction Model via Rough Sets Theory. Int. J. Intell. Syst. Account. Financ. Manag. 2000, 9 , 159-173. [CrossRef]

24. Bărbuță-Mișu, N.; Madaleno, M. Assessment of Bankruptcy Risk of Large Companies: European Countries Evolution Analysis. J. Risk Financ. Manag. 2020, 13, 58. [CrossRef]

25. Fitzpatrick, P. A comparison of ratios of successful industrial enterprises with those of failed firms. Certif. Public Account. 1932, 2, 598-605.

26. Misankova, M.; Bartosova, V. Comparison of Selected Statistical Methods for the Prediction of Bankruptcy. In Proceedings of the 10th International Days of Statistics and Economics, Prague, Czech Republic, 8-10 September 2016; pp. 1260-1269. Available online: https:/ / msed.vse.cz/msed_2016/article/205-Misankova-Maria-paper.pdf (accessed on 8 October 2021).

27. Valášková, K.; Švábová, L.; Durica, M. Verifikácia predikcných modelov v podmienkach slovenského pol'nohospodárskeho sektora. Ekon. Manag. Inovace 2017, 9, 30-38.

28. Ravi, K.P.; Ravi, V. Bankruptcy prediction in banks and firms via statistical and intelligent techniques-A Review. Eur. J. Oper. Res. 2007, 180, 1-28. [CrossRef]

29. Dixon, C. Why the Global Financial Crisis Had So Little Impact on the Banking Systems of Emergent East Asia. J. Self-Gov. Manag. Econ. 2016, 4, 28-62.

30. Fisher, R. The use of multiple measurements in taxonomic problems. Ann. Eugen. 1936, 7, 179-188. [CrossRef]

31. Cornfield, J. Discriminant Funcions. Rev. Int. Stat. Inst. 1967, 35, 142-153. [CrossRef]

32. Maddala, G.S. Introduction to Econometrics, 2nd ed.; Macmillan Publishing Company: New York, NY, USA, 1992.

33. Mika, S.; Ratsch, G.; Weston, J.; Scholkopf, B.; Muller, K.R. Fisher discriminant analysis with kernels. In Proceedings of the Neural Networks for Signal Processing IX, 1999 IEEE Signal Processing Society Workshop (Cat. No.98TH8468), Madison, WI, USA, 25 August 1999. [CrossRef]

34. Jajuga, K. Statystyczna Teoria Rozpoznawania Obrazów; PWN: Warszawa, Poland, 1990.

35. Beaver, W.H. Financial Ratios as Predictors of Failure. J. Account. Res. 1966, 4, 71-111. [CrossRef]

36. Altman, E.I. Financial Ratios, Discriminant Analysis and Prediction of Corporate 27 Bankruptcy. J. Financ. 1968, 23, 589-609. [CrossRef]

37. Prusak, B. Prognozowanie upadłości przedsiębiorstw-fakty i mity. In Zarządzanie Finansami; Prusak, B., Ed.; Wydawnictwo Politechniki Gdańskiej: Gdańsk, Poland, 2015.

38. Kristóf, T.; Miklós, V. A Comprehensive Review of Corporate Bankruptcy Prediction in Hungary. J. Risk Financ. Manag. 2020, 13, 35. [CrossRef]

39. Mączyńska, E. Ocena kondycji przedsiębiorstwa. (Uproszczone metody). Życie Gospod. 1994, 38, 42-45.

40. Jacobs, O.H.; Oestreicher, A. EDV-Gestütze Jahresabschlußanalyse als Planungas-und Entscheidungsrechnung; Verlag Franz Vahlen: Müchen, Germany, 1989.

41. Kitowski, J. Metody Dyskryminacyjne Jako Instrument Oceny Zagrożenia Upadłością Przedsiębiorstwa; Wydawnictwo Uniwersytetu Rzeszowskiego: Rzeszów, Poland, 2015.

42. Pogodzińska, M.; Sojak, S. Wykorzystanie analizy dyskryminacyjnej w przewidywaniu bankructwa przedsiębiorstw. Acta Univ. Nicolai Copernic. Ekon. 1995, 25, 53-61.

43. Gajdka, J.; Stos, D. Wykorzystanie analizy dyskryminacyjnej w ocenie kondycji finansowej przedsiębiorstwa. In Restrukturyzacja w Procesie Przekształceń i Rozwoju Przedsiębiorstw; Borowiecki, R., Ed.; Wydawnictwo AE w Krakowie: Kraków, Poland, 1996; pp. $56-65$.

44. Hadasik, D. Upadłość Przedsiębiorstw w Polsce i Metody jej Prognozowania; Wydawnictwo Akademii Ekonomicznej w Poznaniu: Poznań, Poland, 1998.

45. Hołda, A. Prognozowanie bankructwa jednostki w warunkach gospodarki polskiej z wykorzystaniem funkcji dyskryminacyjnej $\mathrm{Z}_{\mathrm{H}}$. Rachunkowość 2001, 5, 306-310.

46. Spuchl'áková, E.; Frajtová-Michalíková, K. Comparison of LOGIT, PROBIT and neural network bankruptcy prediction models. In Proceedings of the ISSGBM International Conference on Information and Business Management, Hong Kong, China, 3-4 September 2016; pp. 49-53, ISBN 978-981-09-9757-1. 
47. Wojnar, J. Analiza porównawcza modelowania logitowego i liniowej funkcji dyskryminacyjnej w ocenie ryzyka upadłości spółek giełdowych. Metod. Ilościowe Bad. Ekon. 2015, 16, 201-210.

48. Kasprzyk, B. Modelowanie subiektywnych ocen materialnego poziomu życia. Wiadomości Stat. 2013, $2,15-32$.

49. Ohlson, J.A. Financial Ratios and the Probablistic Prediction of Bancruty. J. Acciunting Res. 1980, 18, 109-131. [CrossRef]

50. Pociecha, J. Podstawowe modele prognozwania bankurctwa. In Statystyczne Metody Prognozowania Bankructwa w Mniemajacej się Koniunkturze Gospodarczej; Pociecha, J., Ed.; Fundacja Uniwersytetu Ekonomicznego w Krakowie: Kraków, Poland, 2014.

51. Zavgren, C.V. Assessing the vulnerability to failure of American industral firms: A logistic analysis. J. Bus. Financ. Account. 1985, 12, 19-45. [CrossRef]

52. Platt, H.D.; Platt, M.B. Development of a class of stable predictive variables: The case of bankruptcy prediction. J. Econ. Financ. 1990, 17, 31-51. [CrossRef]

53. Hołda, A. Optymalizacja i Model Zastosowania Procedur Analitycznych w Rewizji Sprawozdań Finansowych. Ph.D. Thesis, Akademia Ekonomiczna w Krakowie, Kraków, Poland, 2000.

54. Gruszczyński, M. Modele mikroekonometrii w analizie i prognozowaniu zagrożenia finansowego przedsiębiorstw. Inst. Nauk Ekon. PAN 2003, 34, 18-20.

55. Wędzki, D. Zastosowanie logitowego modelu upadłości przedsiębiorstw. Ekonomista 2005, 5, 691-705.

56. Prusak, B. Nowoczesne Metody Prognozowania Zagrożenia Finansowego Przedsiębiorstwa; Difin: Warszawa, Poland, 2005.

57. Lichota, W. Zastosowanie modeli logitowych do zdiagnozowania zagrożenia bankructwem przedsiębiorstw. Polityki Eur. Finans. I Mark. 2020, 24, 92-103. [CrossRef]

58. Bellovary, J.L.; Giacomino, D.E.; Akers, M.A. A Review of Bankruptcy Prediction Studies: 1930 to Present. J. Financ. Educ. 2007, $33,1-42$.

59. Korol, T. Nowe Podejście do Analizy Wskaźnikowej w Przedsiębiorstwie; Oficyna Wolters Kluwer Polska: Warszawa, Poland, 2013; p. 158.

60. Sfakianakis, E. Bacruptcy predition model for listed companies in Greece. Investig. Manag. Financ. Innov. 2021, 18, 166-180. [CrossRef]

61. Puagwatana, S.; Gunawardana, K. Logistic Regression Model for Business Failures Prediction of Technology Industry in Thailand. 2012. Available online: https://ssrn.com/abstract=2932026 (accessed on 8 October 2021).

62. Durica, M.; Valaskova, K.; Janoskova, K. Logit business failure prediction in V4 countries. Eng. Manag. Prod. Serv. 2019, 11, 54-64. [CrossRef]

63. Kitowski, J. Metody dyskryminacyjne oceny kondycji finansowej przedsiębiorstw-bariery wiarygodnego stosowania. Ann. H-Oeconomia 2018, 52, 52-59.

64. Belyaeva, E. On a New Logistic Regression Model for Bankruptcy Prediction in the IT Branch; Department of Mathematics, Uppsala University: Upssala, Sweden, 2014.

65. Halteh, K. Bankruptcy prediction of industry-specific businesses using logistic regression. J. Glob. Acad. Inst. Bus. Econ. 2015, 1, 151-163.

66. Wardzińska, K. Przykład zastosowania analizy dyskryminacyjnej do oceny sytuacji finansowej przedsiębiorstw. Econ. Manag. 2012, 3, 197-208.

67. Diez, F.J.; Duval, R.A.; Fan, J.; Garrido, J.; Kalemli-Özcan, S.; Maggi, C.; Peria, M.M.S.M.; Pierri, N. Insolvency Prospects Among Small-and-Medium-Sized Enterprises in Advanced Economies: Assessment and Policy Options. Int. Monet. Fund 2021, $2021,2$. [CrossRef]

68. Zaleska, M. Ocena Ekonomiczno-Finansowa Przedsiębiorstwa Przez Analityka Bankowego; Oficyna Wydawnicza SGH: Warszawa, Poland, 2002.

69. Pitera, R. Credibility of foreign discriminatory models in relation to the assessment of the financialcondition of polish enterprises. Case study of E. Altman's method. Financial Internet Quarterly. e-Finanse 2019, 15, 21-28.

70. Kitowski, J. Krytyczna analiza stosowania metody Edwarda Altmana w badaniu sprawozdań finansowych. Pr. Nauk. Uniw. Ekon. we Wrocławiu 2018, 513, 205-212. [CrossRef]

71. Alihodžić, A. Testiranje primene Kralicekovog DF pokazatelja na Beogradskoj berzi. Bankarstvo 2013, 42, 70-95.

72. Muminović, S. Revaluation and Altman's Z-score-The case of the Serbian capital market. Int. J. Financ. Account. 2013, 2, 13-18.

73. Pavlović, V.; Muminović, S.; Cvijanović, J.M. Adekvatnost Taffler-ovog modela za predikciju bankrotstva srpskih kompanija Appropriateness of Taffler model for predicting bankruptcy of Serbian companies. Industrija 2011, 4, 57-70.

74. Pavlović, V.; Muminović, S.; Cvijanović, J.M. Application of Sandin\&Porporato's bankruptcy prediction model on Serbian companies. Industrija 2011, 2, 1-13.

75. Pavlović, V.; Muminović, S.; Cvijanović, J.M. Adequateness of applying the Zmijewski model on Serbian companies. Industrija 2012, 40, 25-39.

76. Bešlić Obradović, D.; Jakšić, D.; Bešlić Rupić, I.; Andrić, M. Insolvency prediction model of the company: The case of the Republic of Serbia. Econ. Res.-Ekon. Istraživanja 2018, 31, 139-157. [CrossRef]

77. Kitowski, J. Metody dyskryminacyjne w badaniu sprawozdań finansowych. Zesz. Nauk. Uniw. Szczecińskiego Finans. Rynk. Finans. Ubezpieczenia 2015, 74, 103-116. Available online: http://bazekon.icm.edu.pl/bazekon/element/bwmeta1.element.ekonelement-000171397613 (accessed on 22 January 2022). 
78. Micherda, B. Analiza finansowa w badaniu sprawozdania finansowego w świetle Międzynarodowych Standardów Rewizji Finansowej. Zesz. Nauk. Akad. Ekon. Krakowie 2006, 702, 5-21.

79. Hamrol, M. Niedoceniane aspekty badania sprawozdania finansowego przedsiębiorstwa. Zesz. Nauk. Uniw. Szczecińskiego Finans. Rynk. Finans. Ubezpieczenia 2013, 59, 123-132. Available online: http://yadda.icm.edu.pl/yadda/element/bwmeta1.element. ekon-element-000171234281 (accessed on 22 January 2022).

80. Altman, E.I.; Haldeman, R.; Narayanan, P. ZETA TM Analysis. A new model to identify bankruptcy risk of corporations. J. Bank. Financ. 1977, 1, 29-54. [CrossRef]

81. Dorozik, L. (Ed.) Restrukturyzacja Ekonomiczna Przedsiębiorstwa; PWE: Warszawa, Poland, 2006.

82. Klieštika, T.; Kočišová, K.; Mišanková, M. Logit and Probit Model used for Prediction of Financial Health of Company. Procedia Econ. Financ. 2015, 23, 850-855. [CrossRef]

83. Piróg, A. Aplikacja modeli dyskryminacyjnych w ocenie kontynuacji działalności firmy. Zesz. Nauk. Uniw. Ekon. W Katowicach 2016, 284, 187-199.

84. Grzegorzewska, E. Predictive bankruptcy models as a tool in evaluating the economic situation of furniture market in Poland. Ann. Wars. Univ. Life Sci.-SGGW. For. Wood Technol. 2016, 94, 261-267.

85. Appenzeller, D.; Szarzec, K. Prognozowanie zagrożenia upadłością polskich spółek publicznych. Rynek Termin. 2004, 1, 120-128

86. Maślanka, T. Przeptywy Pieniężne w Zarządzaniu Finansami Przedsiębiorstw; Wydawnictwo C.H. Beck: Warszawa, Poland, 2008.

87. Prusak, B. Ocena zagrożenia upadłością produkcyjnych spółek kapitałowych w Polsce w latach 1998-2002. In Upadłość Przedsiębiorstw w Polsce w Latach 1990-2003: Teoria i Praktyka; Appenzeller, D., Ed.; Wydawnictwo Akademii Ekonomicznej w Poznaniu: Poznań, Poland, 2004.

88. Korol, T. Systemy Ostrzegania Przedsiębiorstw Przed Ryzykiem Upadłości; Oficyna Wolters Kluwer: Warszawa, Poland, 2010.

89. Waszkowski, A. Methods of classification models for enterprises insolvency prediction. Acta Sci. Pol. Oeconomia 2021, 10, 95-106.

90. Altman, E.I. A Further Empirical Investigation of Bankruptcy Costs. J. Financ. 1984, 9, 1067-1089. [CrossRef]

91. Stępień, P.; Strąk, T. Wielowymiarowe modele logitowe oceny zagrożenia bankructwem polskich przedsiębiorstw, In Czas na pieniądz. Zarządzanie finansami. Finansowanie przedsiębiorstw w Unii Europejskiej; Zarzecki, D., Ed.; Wydawnictwo Uniwersytetu Szczecińskiego: Szczecin, Poland, 2004.

92. Altman, E.I.; Hotchkiss, E. Trudności Finansowe a Upadłość Firm; CeDeWu: Warszawa, Poland, 2007.

93. Lichota, W. Metody wczesnego ostrzegania o zmianach sytuacji finansowej przedsiębiorstw. Wiadomości Stat. 2009, 10, 24-34. 